\title{
VITAMIN A STORAGE IN THE LIVER OF CERTAIN AFRICAN WILD RUMINANTS AND ELEPHANT
}

C. BARTELMUS, D. GIESECKE

Institut für Tierphysiologie,

Universität München

8 München 22

Veterinärstrasse 13

Germany

and

P. HOPPE

Department of Animal Physiology

University of Nairobi

P. O. 30197

Nairobi

Kenya

Abstract - The levels of vitamin A were determined in liver samples from 40 animals including ruminant spesies feeding on grass ( 4 buffalo, 6 blue wildebeest, 5 gemsbok) or mainly on plant material other than grass (10 impala, 3 springbok, 7 kudu and 5 elephants). The mean values obtained for the ruminant species ranged from 212 to 1217 I.U. vitamin A/g liver fresh weight mass and showed no relationship to the percentage of grass in rumen contents. An unusually low level of 67 I.U. was found in elephant.

\section{Introduction}

The role of vitamin A as an essential precursor of the visual purple is well known. More recent reports have emphasized its importance for growth, fertility and resistance against infections (Tiews and Hoppe 1972). Within certain limits the dietary supply of $B$-carotene, the main precursor of vitamin A, is reflected by the storage of vitamin A in the liver (Moore 1957).

However, definite differences between species are obvious. In a study of the physiological levels of vitamin A in European wild ruminants the question was raised whether liver storage is related to the feeding habits of the various species (Brüggemann, Drescher-Kaden, Hoppe and Walser-Kärst 1970).

A co-operative investigation of rumen digestive physiology in South African wild ruminants (Van Gylswyk and Giesecke 1973), offered an opportunity to examine liver samples of species feeding either strictly on grass or on plant material other than grass. Samples of elephant liver were also made available. 
A total of 40 adult animals representing 7 species ( 4 buffalo Syncerus caffer, 6 blue wildebeest Connochaetes taurinus, 5 gemsbok Oryx gazella, 10 impala Aepyceros melampus, 3 springbok Antidorcas marsupialis, 7 kudu Tragelaphus strepsiceros and 5 elephant Loxodonta africana) were sampled during the dry season from the end of July to the end of September 1971 in localities shown in Table 1. Most liver samples were excised within one hour (in exceptional cases within two hours) after death. The samples were hydrolysed immediately in $\mathrm{KOH}(10 \% \mathrm{w} / \mathrm{v}$ in ethanol) under $\mathrm{O}_{2}$-free conditions, or preserved in liquid nitrogen. After hydrolysis the ether-extraction and spectrophotometric measurement at $325 \mathrm{~nm}$ was performed as described elsewhere (Brüggemann et al. 1970).

\section{Results and Discussion}

The results are given in Table 1 as mean values with standard errors of the various species. The ruminant species are grouped according to their feeding habits. As indicated by cursory botanical analyses of rumen contents (Van Gylswyk et al. 1973), buffalo, blue wildebeest and gemsbok could be termed true grazers, grass representing almost $100 \%$ of the diet. Impala, springbok and kudu were essentially browsers at this time of the year, as grass constituted less than $10 \%$ of the total mass of samples.

Table 1

Characteristics of animals sampled and vitamin A content of liver

\begin{tabular}{|c|c|c|c|c|}
\hline $\begin{array}{l}\text { Animal } \\
\text { species }\end{array}$ & Locality of sample & $\begin{array}{c}\text { Number } \\
\text { of } \\
\text { animals }\end{array}$ & $\begin{array}{l}\text { Percentage of } \\
\text { grass in rumen } \\
\text { contents: }\end{array}$ & $\begin{array}{l}\text { Vitamin A } \\
\text { content of liver } \\
\text { (I.U. vitamin } \\
\text { A/g fresh mass) }\end{array}$ \\
\hline Buffalo & $\begin{array}{l}\text { Kruger National Park } \\
\text { Addo Elephant Park }\end{array}$ & $\begin{array}{l}3 \\
1\end{array}$ & $\begin{array}{r}100 \\
15\end{array}$ & $\begin{array}{c}365 \pm 195^{* * *} \\
-\end{array}$ \\
\hline $\begin{array}{l}\text { Blue wilde- } \\
\text { beest }\end{array}$ & Kruger National Park & 6 & 100 & $1217 \pm 145$ \\
\hline Gemsbok & $\begin{array}{l}\text { Kalahari Gemsbok Park } \\
\text { Sandheuwel, S.W.A. }\end{array}$ & $\begin{array}{l}3 \\
2\end{array}$ & $\begin{array}{l}96 \\
-\end{array}$ & $21 \overline{-} \pm 212$ \\
\hline Impala & Kruger National Park & 10 & 4 & $574 \pm 234$ \\
\hline Springbok & Kalahari Gemsbok Park & 3 & 10 & $619 \pm 96$ \\
\hline Kudu & $\begin{array}{l}\text { Kruger National Park } \\
\text { Thornkloof, Eastern Cape }\end{array}$ & $\begin{array}{l}2 \\
5\end{array}$ & $\begin{array}{l}7 \\
2\end{array}$ & $\begin{array}{c}516 \pm 295 \\
-\end{array}$ \\
\hline Elephant & Kruger National Park & 5 & - & $67 \pm 10$ \\
\hline
\end{tabular}

* Per cent of identifiable plant material on dry mass basis (after Van Gylswyk and Giesecke 1973)

*: Mean values \pm standard errors 
The concentration of vitamin A in liver samples varied greatly between species. No obvious relation to the feeding type existed as, with the exception of elephant, both the highest and the lowest levels were found in two of the grazing species viz. blue wildebeest and gemsbok. The browsers, impala, springbok and kudu showed relatively uniform values of vitamin A storage. It would thus appear that the levels of vitamin $\mathrm{A}$ in the liver are mainly governed by factors characteristic of the animal species rather than of the feeding habits.

In this context the extremely low content of vitamin A in the liver of elephant, a species mainly feeding on green leaves, is worth nothing. As in cattle, sheep and horses, the mass of the liver of elephants constitutes about 1-1,5\% of total body mass (Sikes 1971). Thus, the low level of vitamin $\mathrm{A}$ is not compensated by the mass of the liver relative to body mass.

Vitamin A storage in the liver of buffalo is of the same order of magnitude as in domestic cattle but considerably lower than in the European wild bovids, mouflon Ovis musimon and chamois Rupicapra rupicapra with respective mean values of about 1600 and 800 to 1500 I.U. per g liver fresh mass (Brüggemann et al.1970). B-carotene was only found in trace amounts in the livers of species investigated. This is in accordance with domestic ruminants in which the liver storage of $\mathrm{B}$-carotene is minimal as compared to vitamin $\mathrm{A}$.

As indicated by the standard errors of the mean values given in Table 1 , the variation within species was considerable. A similar degree of variability observed in European wild ruminants could be attributed in part to differences in age, sex and season (Brüggemann et al. 1970). The present data, including mostly both sexes and only one season, would not lend themselves for such comparison because of the small numbers of animals examined. In European species an additional important factor was infection with ecto- or endoparasites, which was shown to lower vitamin A levels to roughly one third of the normal values depending on the degree of infection. Even though the animals sampled in the present study were not examined systematically for parasites, all the elephants were found heavily infected with intestinal parasites as well as the gemsbok obtained from the Kalahari Gemsbok National Park. This may explain in part the low mean values of vitamin A storage in the livers of these species, and a more thorough investigation may be rewarding.

\section{Acknowledgements}

The authors are indebted to the National Parks Board of Trustees for permission to undertake the study and to Dr. G. de Graaff for organizing the excursions. Two of the authors (C. B. and D. G.) would like to thank Dr. Helen M. Schwartz and the National Chemical Research Laboratory of the C.S.I.R. for support and encouragement and all colleagues of the D.M.R. Unit at Onderstepoort for advice and helpful assistance. 


\section{REFERENCES}

BRÜGGEMANN, J., U. DRESCHER-KADEN, P. HOPPE and K. WALSER-KÄRST. 1970. Untersuchungen über den Vitamin AGehalt in der Leber von Wildtieren. I. Mitteilung: Vitamin ALeberspeicher bei wildlebenden Wiederkäuern. Internat. J. Vit. Res. 40:249-259.

MOORE, T. 1957. Vitamin A, Amsterdam: Elsevier.

SIKES, S. K. 1971. The natural history of the African elephant. London: Weidenfeld and Nicholson.

TIEWS, J. and P. HOPPE. 1972. Vitamine. World Congress of Animal Nutrition IV:275-295.

VAN GYLSWYK, N. O. and D. GIESECKE. 1973. A summary of preliminary findings in a rumen microbiological investigation on wild ruminants. Koedoe 16:191-194. 